part of the spectrum. We ascertained the point of extinction and the point of reappearance of light from all parts of the spectrum. F. W. EDRIDGE-GrEEN.

London, December 25, I9r2.

The late Mr. Leigh Smith and Novaya Zemlya.

MAX I be allowed to point out to you that there is an omission in the short notice your publication quoted from The Times on the death of Mr. Leigh Smith?

Your countryman was found and rescued on the west coast of Novaya Zemlya, near the mouth of Matotschkin Sharr, by Captain J. Dalen, Dutch R.N., who was in command of the Dutch exploration vessel, Willem Barents. Sir Allan Young, in the Hope, was near, but Leigh Smith and his men did not know it when they were found and directed to the English ship by the Dutchmen. This occurred on August 3, 1882 .

Next year, when the Willem Barents again left for exploration work in northern waters, Sir Clements Markham and Mr. Leigh Smith came over to Amsterdam and presented two fine silver cups to the president of the Dutch Committee for Polar Research Work in kind remembrance of his being seen and brought to safety by Captain Dalen and his crew.

This act of courtesy by Mr. Leigh Smith was much appreciated by our countrymen.

Rotterdam, January ro.

$$
\text { W. H. R. v. MANEN. }
$$

\section{COUNTRIES AND CUSTOMS. ${ }^{1}$}

(I) THE jealousy of the State Government country in the Empire among the least-known we maintain friendly relations. To a student of art like the writer it is peculiarly interesting, because it forms a link between India and Tibet. Mr. Brown was allowed some liberty in visiting the sacred sites in the valley; but if he secured any new information on geography or politics he has not disclosed it. On the subject of Newar art he gives us some valuable facts and impressions. The Gorkhas, now the ruling caste, have contributed little to the art treasures of the country, and the art of the Newars represents a Tibetan substratum largely influenced from India. But it is the India of the Middle Ages, not that of the present day, when the people have come under foreign control, Mohammedan or British. The book is provided with many fine photographs, and a few sketches in colour to illustrate Newar architecture and work in metal, stone and wood. The author traces with skill the varied influences which have contributed to establish the Nepalese art school, and he gives some interesting facts, partly in corroboration, partly in extension, of those admirable essays on local religion and custom for which we are indebted to the late Dr. H. A. Oldfield. The pleasant, unaffected style in which these notes are recorded makes them more valu-

.1 (r) "Picturesque Nepal." By Percy Brown. Pp. xvi+205. (I.ondon : $A$ and C. Black, r912.) Price 7s. $6 d$. net.

(2) "Papua or British New Guinea." By J. H. P. Murray. With an Introduction by Sir William MacGregor, G.C.M.G., C.B. ${ }^{\text {Pp. }} 3^{88+}$ plates +map. (London: T. Fisher Unwin, 19r2.) Price r5s. net.

(3) "Through Shên-Kan. The Account of the Clark Expedition in North China, rgo8-9." By Robert Sterling Clark and Arthur de C. Sowerby. (Lon ton (Lon lon: T. Fisher Unwin, 1912.) Price 25s. net. NO. 2255 , VOL. gO] able than those which usually accompany books the claim of which to support lies in the illustrations alone.

(2) Our knowledge of Papua is rapidly increasing. Mr. R. Williamson's book on the Mafulu Mountain People, the work of an explorer and expert in ethnology and law, has been soon followed by the present work, which is of quite a different class. Mr. Murray admits his lack of scientific knowledge in ethnology, geology, botany, and indeed in any other branch of science; but he enjoys the advantage of long experience of the country, and Sir W. MacGregor assures us that "he has had opportunities of seeing into the heart of things in New Guinea in a way that no previous writer could ever lay claim to." This opinion is justified by the study of his book. He begins with a careful geographical account of the British province, followed by a history of the island from the age of the first explorers, an exhaustive account of the native tribes, of the methods under which the Australian officers administer justice, and of the progress in developing the resources of the country. The book is provided with a fairly adequate map and a good series of photographs.

In an interesting introduction, Sir W. MacGregor describes the task which lay before the new officials, the establishment of a land system, criminal and civil legislation. He concludes that "the two finest and best institutions I left in New Guinea were the constabulary and village police, and the missions." The book is almost purely ethnographical. The Papuo-Melanesians, he thinks, were the result of more than one immigration; but he declines to dogmatise on the origin and affinities of the Papuans. Students of cannibalism will find full details of the custom in a repulsive form. Most interesting, and full of instruction to other administrators whose lot lies among savage peoples, is the account of the methods by which the natives are being gradually civilised, and how a system of law, adopting all that is useful among the indigenous institutions, has been introduced. The book may be safely recommended as an instructive account of some of the wildest races in the Empire.

(3) The fine volume which describes this attempt to explore North China is, to some extent, the record of a failure. In the expedition organised and financed by Mr. R. S. Clark, of New York, it was proposed to start from T'ai-yuan $\mathrm{Fu}$, in Shansi, and after traversing Shên-Kan, i.e., the provinces of Shansi and Kansu, to skirt the Tibetan border to Ching-tu Fu, in Schuch'uan; then to descend the Min River to Sui-fu or Hsuchou $\mathrm{Fu}$, and return to Shanghai via the Yang-tzu. Its primary objects were-a careful plane-table survey of the whole route followed, astronomical observations for latitude and longitude at all important towns, to observe the meteorological conditions, to collect specimens, and to use photography in various ways. The work of the survey was placed in charge of a Punjabi surveyor, Hazrat Ali; Captain Douglas, V.C., D.S.O., of the Royal Army Medical Staff, was allowed by the 